\title{
Disposable baby diapers: Life cycle costs, eco-efficiency and circular economy
}

DOI:

10.1016/j.jclepro.2018.11.146

\section{Document Version}

Accepted author manuscript

Link to publication record in Manchester Research Explorer

\section{Citation for published version (APA):}

Mendoza, J. M. F., D'aponte, F., Gualtieri, D., \& Azapagic, A. (2018). Disposable baby diapers: Life cycle costs, eco-efficiency and circular economy. Journal of Cleaner Production. https://doi.org/10.1016/j.jclepro.2018.11.146

\section{Published in:}

Journal of Cleaner Production

\section{Citing this paper}

Please note that where the full-text provided on Manchester Research Explorer is the Author Accepted Manuscript or Proof version this may differ from the final Published version. If citing, it is advised that you check and use the publisher's definitive version.

\section{General rights}

Copyright and moral rights for the publications made accessible in the Research Explorer are retained by the authors and/or other copyright owners and it is a condition of accessing publications that users recognise and abide by the legal requirements associated with these rights.

\section{Takedown policy}

If you believe that this document breaches copyright please refer to the University of Manchester's Takedown Procedures [http://man.ac.uk/04Y6Bo] or contact uml.scholarlycommunications@manchester.ac.uk providing relevant details, so we can investigate your claim.

\section{OPEN ACCESS}




\title{
Disposable baby diapers: life cycle costs, eco-efficiency and circular economy
}

\author{
Joan Manuel F. Mendoza ${ }^{{ }^{*}}$, Francesco D'Aponte ${ }^{2}$, Diego Gualtieri ${ }^{2}$ and Adisa Azapagic ${ }^{1^{*}}$ \\ ${ }^{1}$ Sustainable Industrial Systems, School of Chemical Engineering and Analytical Science, \\ The Mill, The University of Manchester, Sackville Street, M13 9PL Manchester, United \\ Kingdom. \\ ${ }^{2}$ Fameccanica.Data SpA, Via Volta 10, 65129 Pescara, Italy.
}

Corresponding authors $\left(^{*}\right)$ : adisa.azapagic@manchester.ac.uk; joanmanuel.fm@gmail.com.

\begin{abstract}
The literature on baby diapers has so far focused on environmental implications of using cloth instead of disposable products, utilising bio-materials or enabling recycling and composting. However, no study to date has examined the life cycle costs and eco-efficiency implications of cleaner production of disposable diapers. Therefore, this paper sets out to evaluate the economic and environmental savings that could be achieved by eco-design and cleaner production of disposable baby diapers. This involves the use of an optimised absorbent core and innovative bonding technologies to replace gluing systems in diaper manufacturing. The analysis is carried out at different production and consumption scales: a single production platform, a whole industrial plant, a country and the European Union (EU). A cradle-to-grave life cycle costing demonstrates that the novel design and manufacture of the so-called "glueless" diapers reduce costs by $11 \%$ compared to the conventional product. This is equivalent to saving $€ 250$ million at the EU level. Likewise, the eco-efficiency analysis shows that the glueless diapers are $7 \%-170 \%$ more eco-efficient (€/impact) than the standard diapers, depending on the environmental impact considered. Still, eco-design and cleaner production will not help to resolve the underlying critical issue of the linear material consumption and waste generation associated with the use of disposable baby diapers. Further industrial efforts must concentrate on finding solutions to facilitate implementation of circular economy principles for these products. This calls for the development of new circular business models as discussed in the paper.
\end{abstract}

Keywords: Absorbent hygiene products; Cleaner production; Life cycle assessment; Resource efficiency; Sustainable business models

\section{Introduction}

The emergence of absorbent hygiene products (AHPs) has contributed towards improving the quality of life of millions of people through better hygiene, skin protection and convenience (EDANA, 2015). AHPs comprise disposable baby diapers, feminine sanitary products, personal care wipes and adult incontinence products. In the EU, disposable baby diapers are the leading AHPs, occupying 36\% of the market (Euromonitor International, 2015). This translates to an annual consumption of over 21 billion units in the EU alone (Euromonitor International, 2015). Considering a retail price of $€ 0.20$ for a single disposable baby diaper, the consumption of these products represents an annual economic expenditure of $€ 4.2$ billion, which is equivalent to the annual net earnings of over 240,500 single people without children in the EU (Eurostat, 2017).

Almost $700 \mathrm{kt}$ of raw materials are consumed annually to manufacture disposable baby diapers, excluding packaging (Mendoza et al., 2019). The volume of diaper waste (dry weight) generated every year in the $\mathrm{EU}$ is equivalent to the annual municipal waste produced by over 1.4 million people (Eurostat, 2018a). Likewise, the manufacture, distribution, use and waste management of diapers emit 2.7 Mt of greenhouse gases (GHG) per year (Cordella et al., 2015; Mendoza et al. 2018). This is equivalent to the annual GHG emissions of over 1.5 million EU households (EEA, 2013; EEA, 2014). 
The environmental literature on baby diapers has mainly focused on life cycle assessment (LCA) and comparison of disposable and cloth diapers (Environment Agency, 2008; O'Brien et al., 2009). Several studies also considered optimising material efficiency of disposable diapers (Weisbrod and Van Hoof, 2011; Cordella et al., 2015). Potential advantages of using bio-based materials have also been studied (Clancy et al., 2013; Mirabella et al., 2013; Gontia and Janssen, 2016). Furthermore, end-of-life recycling (Arena et al., 2016) and composting (Colon et al., 2010; Espinosa-Valdemar et al., 2014) have also been discussed in the literature.

However, no study has analysed the economic performance and eco-efficiency of different diaper manufacturing and product alternatives. This knowledge gap might limit the potential to develop future sustainability strategies in the diaper industry. For instance, life cycle costing (LCC) is considered essential for connecting environmental concerns with core business strategies (Jensen and Remmen, 2006). Likewise, eco-efficiency - creating more value at lower environmental impacts - encourages businesses to search for environmental improvements that also lead to economic benefits (WBCSD, 2006). Consequently, the application of LCC and eco-efficiency approaches can stimulate creativity and aid sustainability innovations in the diaper industry.

Thus, this paper presents for the first time a comparative LCC and eco-efficiency analysis of standard and re-designed disposable diapers. The later have an optimised absorbent core, the key component of a diaper, and are manufactured using alternative bonding techniques, such as thermo-mechanical and ultrasonic, to eliminate the use of gluing systems. Hence, they are referred to here as "glueless" diapers. The analysis is carried out at four levels: a single production platform, an industrial plant, a country and the EU, in an attempt to determine the magnitude of potential economic and environmental savings through cleaner production of diapers. The potential for implementation of different circular economy strategies in the diaper industry is also discussed.

\section{Methodology}

Figure 1 provides an overview of the research methodology used in this work to analyse and compare the life cycle economic and environmental sustainability of standard and glueless disposable baby diapers. As can be seen in the figure, this has involved carrying out LCC and LCA of both types of diaper. These results have then been combined to determine and compare their eco-efficiency. The outcomes have been used, alongside the findings of a literature review carried out for the purposes of this work, to discuss the feasibility of different circular economy strategies that could be implemented in the diaper industry. The following sections describe the methods in more detail. 


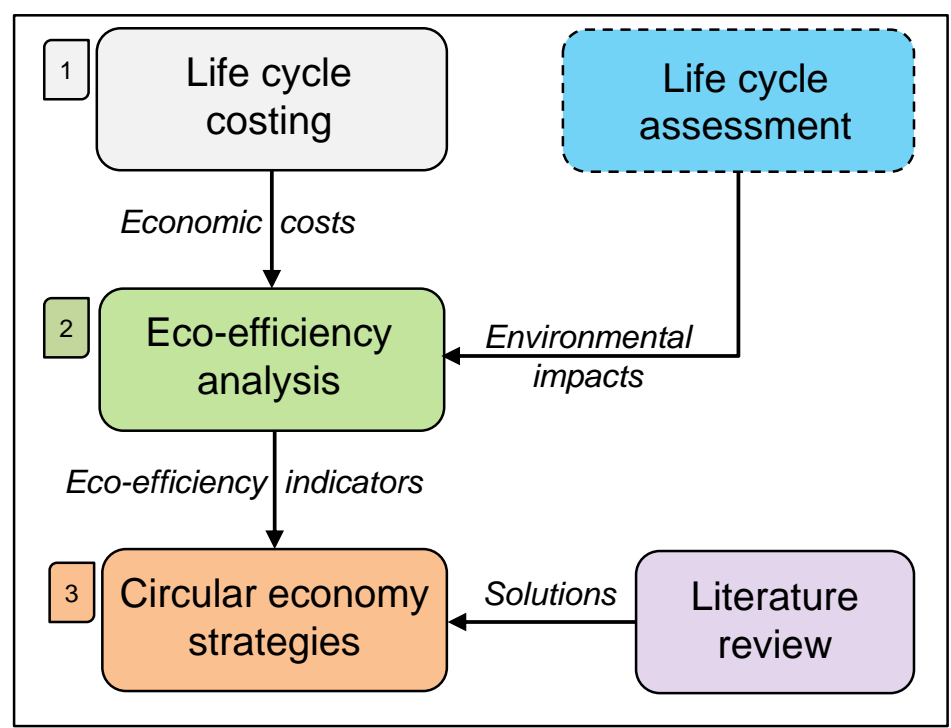

Figure 1 An overview of the methodological steps (---- From Mendoza et al. (2019). CE: circular economy).

\subsection{Life cycle costing}

The LCC of the standard and glueless diapers has been performed following the guidelines in Hunkeler et al. (2008) and Swarr et al. (2011). This is also congruent with the LCA approach specified in the ISO 14040-44 standards (ISO 2006a, 2006b). The goal and the scope of the study are defined below, followed by the inventory data and assumptions used in the study.

\subsubsection{Goal and scope}

The main goals of the study are:

i. to determine and compare the costs of standard and glueless disposable baby diapers;

ii. to identify hot-spots and opportunities for improvements; and

iii. to estimate the annual costs of manufacturing the glueless diapers at different scales (production platform, industrial plant, country and the EU) and compare to the costs of standard diapers.

These results are then combined with the LCA results reported elsewhere (Mendoza et al., 2019) and used for the eco-efficiency analysis, as discussed in section 2.2.

For the first two goals of the study, the functional unit is defined as the "manufacture and use of 1,000 disposable baby diapers". This functional unit is congruent with the production technology considered in this research which produces 1,000 diapers per minute (section 2.1.2). This technology is also representative of the European market (Mendoza et al., 2019). For the third goal, the functional unit is the "annual manufacture and use of disposable baby diapers at different scales".

As indicated in Figure 2, the scope of the study is from cradle to grave, excluding the use of diapers, as that is common to both types of product. The following life cycle stages and costs are included in the study:

- production and acquisition of raw materials;

- operation and maintenance of the equipment ("P10" platform) to produce diapers;

- labour costs; and

- process and post-consumer waste management (recycling, incineration and landfill).

These are discussed further in the next section. 


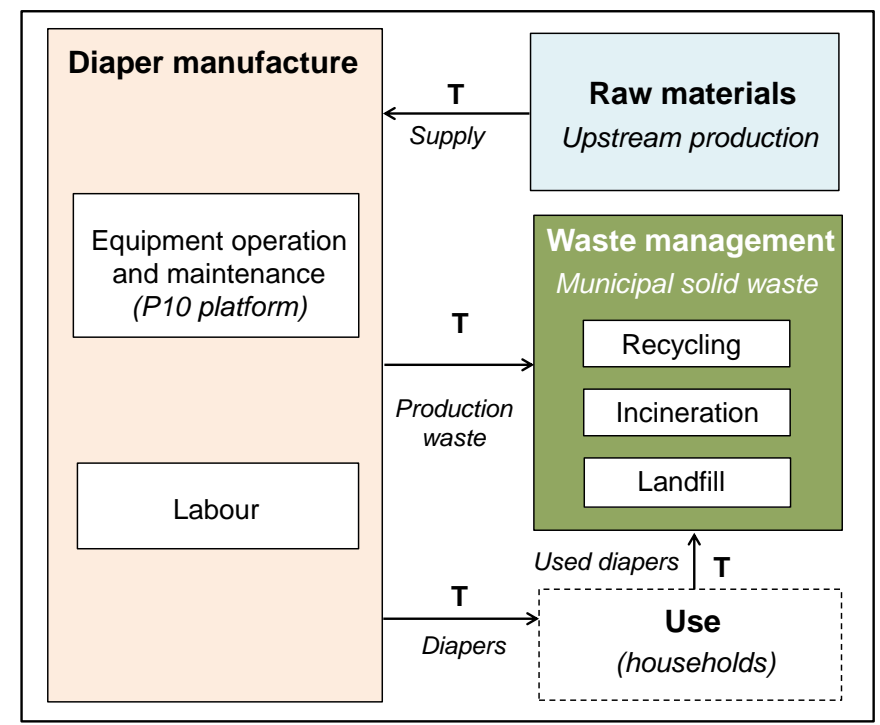

Figure 2 Scope of the LCC study and system boundaries (adapted from Mendoza et al. (2019)).

(----- Excluded from the system boundary. P10 production platform: production of 1000 diapers per minute (Fameccanica 2018). T: Transport).

\subsubsection{System description}

The raw materials used in diaper manufacturing are processed upstream and supplied to the diaper producer (Figure 2). These are then cut, shaped and assembled in automated production modules in diaper manufacturing plants. In the production of standard diapers, almost all the materials are bonded together using glue (hot-melt adhesive). Different type of equipment is required to glue the materials, including fusers, pumps, glue applicators and chillers.

However, the gluing process can be replaced by a combination of thermo-mechanical and ultrasonic bonding technologies, as described in Table 1. Likewise, the absorbent core of the diapers can be optimised by adjusting the ratio of the fluff pulp and superabsorbent polymer (SAP) from $40 / 60$ to $20 / 80(\mathrm{w} / \mathrm{w}$ ) through process re-engineering. These process innovations have been developed, tested and implemented at the industrial scale by Fameccanica SpA, a global manufacturer of specialised machinery for production of AHPs, including baby diapers and sanitary towels. A P10 production platform, which stands for the manufacture of a 1,000 premium diapers per minute, has been used to validate the performance of the new design and manufacturing of diapers. A more detailed description of these innovations can be found in Fameccanica (2018). For a comprehensive description of the standard and glueless product systems as well as the manufacturing chain, see Mendoza et al. (2019). Here, we proceed to describe the LCC methodology applied in the paper.

\subsubsection{Estimation of life cycle costs}

The LCC of standard and glueless diapers have been estimated using the following equation:

$$
L C C=C_{R M}+C_{M}+C_{T}+C_{W M}
$$

where:

$C_{R M}$ costs of raw materials, including packaging $(€)$

$C_{M} \quad$ costs of diaper manufacturing, including operation and maintenance of equipment and labour $(€)$

$C_{T} \quad$ costs of transport, including raw materials distribution to the manufacturing plant, diaper transport to households and transport of production and household wastes to waste management plants $(€)$ 
$C_{W M}$ costs of waste management, including recycling (packaging only), incineration with energy recovery and landfilling $(€)$.

Only the five unit operations shown in Table 1 where gluing can be replaced by alternative bonding technologies have been considered to estimate the diaper manufacturing costs. All other manufacturing stages are the same for both the standard and glueless diapers and hence not considered. The use stage is also excluded from the system boundaries (Figure 2) because the retail price of the glueless diapers could not be determined as they are not available on the market yet.

Table 1 Innovations in the manufacture of glueless baby diapers (based on Fameccanica 2018).

\begin{tabular}{|c|c|c|}
\hline Unit processes & Diaper layout & Glueless innovations \\
\hline $\begin{array}{l}\text { Glueless }{ }^{\mathrm{IM}} \text { intermitent } \\
\text { elastics }\end{array}$ & & $\begin{array}{l}\text { - Cuff elastics mechanically fixed } \\
\text { between two layers of nonwoven in } \\
\text { intermittent mode } \\
\text { - Equivalent results in terms of } \\
\text { tension-elongation of the standard } \\
\text { application with glue } \\
\text { - Process stability up to } 450 \mathrm{~m} / \mathrm{min} \text { or } \\
1000 \mathrm{ppm}\end{array}$ \\
\hline $\begin{array}{l}\text { Glueless }^{\mathrm{TM}} \text { adquisition } \\
\text { and distribution layer } \\
\text { (ADL) }\end{array}$ & & $\begin{array}{l}\text { - ADL welded on topsheet by using } \\
\text { ultrasonic bonding equipment and a } \\
\text { properly designed pattern. } \\
\text { - Equivalent or improved results in } \\
\text { terms of acquisition time and } \\
\text { wetback of the final diaper element } \\
\text { assembly } \\
\text { - Process stability up to } 450 \mathrm{~m} / \mathrm{min} \text { or } \\
1000 \text { ppm with } 100 \% \text { of flawless } \\
\text { products }\end{array}$ \\
\hline $\begin{array}{l}\text { Glueless }{ }^{\mathrm{TM}} \text { absorbent } \\
\text { core }\end{array}$ & & $\begin{array}{l}\text { mechanical bonding equipment and } \\
\text { a properly designed pattern } \\
\text { - Material optimisation of the core } \\
\text { - Equivalent or improved results in } \\
\text { terms of fluid acquisition and core } \\
\text { Integrity }\end{array}$ \\
\hline $\begin{array}{l}\text { Glueless }^{\mathrm{TM}} \text { frontal tape } \\
\text { construction }\end{array}$ & & $\begin{array}{l}\text { - In line creation of a backsheet with } \\
\text { loop frontal tape, using ultrasonic } \\
\text { bonding equipment } \\
\text { - No compromise of the backsheet } \\
\text { impermeability } \\
\text { - Process stability up to } 450 \mathrm{~m} / \mathrm{min} \text { or } \\
1000 \text { pieces per minute }\end{array}$ \\
\hline $\begin{array}{l}\text { Glueless }^{\mathrm{TM}} \text { back ear } \\
\text { application }\end{array}$ & & $\begin{array}{l}\text { - Confirmed strength of the welding } \\
\text { through the peel test. } \\
\text { - Use of glue applicators a } \\
\text { - Ears thermal application without } \\
\text { glue reinforcement } \\
\text { - Equivalent results in terms of } \\
\text { strength of the side seal } \\
\text { - Welding strength higher than the } \\
\text { breaking point of the ear itself } \\
\text { - Use of glue applicators }\end{array}$ \\
\hline
\end{tabular}




\subsubsection{Inventory data and assumptions}

The life cycle inventory and cost data for the standard and glueless diapers are detailed in Table 2. The inventory data have been sourced from Mendoza et al. (2019). The production costs have been provided by Fameccanica using 2016 as the base year. As the production process is based in Italy, the costs correspond to the Italian context. The costs of waste management and related transport have been determined using industrial and public data sources, as descried below.

Table 2 Life cycle inventory and cost data for standard and glueless baby diapers.

\begin{tabular}{|c|c|c|c|c|c|c|}
\hline \multirow{2}{*}{$\begin{array}{l}\text { Life cycle } \\
\text { stages }\end{array}$} & \multirow{2}{*}{\multicolumn{2}{|c|}{ Diaper components/unit operations/activities }} & \multicolumn{2}{|c|}{ Amount/1,000 diapers } & \multicolumn{2}{|c|}{ Cost $(€ / 1,000$ diapers $)$} \\
\hline & & & Standard & Glueless & Standard & Glueless \\
\hline \multirow[t]{17}{*}{ Raw materials } & Elastic cuffs & $\mathrm{NW}^{\mathrm{a}}$ cuff $(\mathrm{kg})$ & 1.16 & 1.16 & 2.63 & 2.63 \\
\hline & & Elastics $(\mathrm{kg})$ & 0.02 & 0.02 & 0.20 & 0.20 \\
\hline & Topsheet-AD ${ }^{a}$ & $\mathrm{NW}^{\mathrm{a}}$ topsheet $(\mathrm{kg})$ & 1.03 & 1.03 & 2.42 & 2.42 \\
\hline & construction & $\mathrm{ADL}^{\mathrm{a}}(\mathrm{kg})$ & 1.89 & 1.89 & 5.05 & 5.05 \\
\hline & Absorbent core & Upper tissue $(\mathrm{kg})$ & 0.56 & 0.56 & 1.41 & 1.41 \\
\hline & & Lower tissue $(\mathrm{kg})$ & 0.63 & 0.63 & 1.52 & 1.52 \\
\hline & & ATB $^{\mathrm{a}}$ layer $(\mathrm{kg})$ & 0.00 & 2.11 & 0.00 & 6.33 \\
\hline & & Fluff pulp (kg) & 12.70 & 3.03 & 12.12 & 2.89 \\
\hline & & $\operatorname{SAP}^{\mathrm{a}}(\mathrm{kg})$ & 15.15 & 14.14 & 30.30 & 28.28 \\
\hline & Front and elastic back & Elastic NW ${ }^{\mathrm{a}}$ back ears $(\mathrm{kg})$ & 1.55 & 1.55 & 10.10 & 10.10 \\
\hline & ears & $\mathrm{NW}^{\mathrm{a}}$ for front ears $(\mathrm{kg})$ & 0.26 & 0.26 & 0.51 & 0.51 \\
\hline & Composite backsheet & $\mathrm{NW}^{\mathrm{a}}$ backsheet $(\mathrm{kg})$ & 2.24 & 2.24 & 5.05 & 5.05 \\
\hline & with frontal tape & Backsheet film (kg) & 1.88 & 1.88 & 8.08 & 8.08 \\
\hline & & Frontal tape $(\mathrm{kg})$ & 0.21 & 0.21 & 8.08 & 8.08 \\
\hline & Hot-melt adhesive & Glue $(\mathrm{kg})$ & 0.95 & 0.32 & 3.37 & 1.13 \\
\hline & Packaging & Corrugated cardboard (kg) & 0.09 & 0.07 & 0.12 & 0.09 \\
\hline & & Plastic film $(\mathrm{kg})$ & 0.20 & 0.20 & 0.28 & 0.21 \\
\hline \multirow{17}{*}{$\begin{array}{l}\text { Diaper } \\
\text { manufacturing }\end{array}$} & Motors & Electricity (kWh) & 1.00 & 1.03 & 0.18 & 0.18 \\
\hline & & Maintenance (lubricants, kg) & $9.9 \times 10^{-4}$ & $1.0 \times 10^{-3}$ & $4.7 \times 10^{-3}$ & $4.8 \times 10^{-3}$ \\
\hline & Vacuum system & Electricity (kWh) & 1.83 & 1.83 & 0.33 & 0.33 \\
\hline & & Maintenance (lubricants, kg) & $1.8 \times 10^{-3}$ & $1.8 \times 10^{-3}$ & $7.5 \times 10^{-5}$ & $7.5 \times 10^{-5}$ \\
\hline & Chillers & Electricity (kWh) & 0.02 & 0.00 & $4.0 \times 10^{-3}$ & 0.00 \\
\hline & & Maintenance (lubricants, kg) & $2.2 \times 10^{-5}$ & 0.00 & $8.0 \times 10^{-3}$ & 0.00 \\
\hline & Glue applicators & Electricity (kWh) & 0.24 & 0.03 & 0.04 & $6.0 \times 10^{-3}$ \\
\hline & & Maintenance $\left({\mathrm{L} \& S^{\mathrm{a}}}, \mathrm{kg}\right)$ & $5.3 \times 10^{-3}$ & $7.7 \times 10^{-4}$ & $3.1 \times 10^{-1}$ & $3.1 \times 10^{-2}$ \\
\hline & Pneumatic unit & Electricity (kWh) & 0.25 & - & 0.04 & - \\
\hline & & Maintenance (lubricants, kg) & $2.5 \times 10^{-4}$ & - & $2.6 \times 10^{-3}$ & - \\
\hline & Ultrasonic systems & Electricity (kWh) & - & 0.02 & - & $4.0 \times 10^{-3}$ \\
\hline & & Maintenance (lubricants, kg) & - & $2.3 \times 10^{-5}$ & - & $3.0 \times 10^{-3}$ \\
\hline & Thermo-mechanical & Electricity (kWh) & - & 0.08 & - & 0.01 \\
\hline & unit & Maintenance (lubricants, kg) & - & $8.3 \times 10^{-5}$ & - & $5.0 \times 10^{-5}$ \\
\hline & Heat-sealers & Electricity (kWh) & 0.01 & 0.02 & $2.0 \times 10^{-3}$ & $3.5 \times 10^{-3}$ \\
\hline & & Maintenance (lubricants, kg) & $1.1 \times 10^{-5}$ & $1.8 \times 10^{-5}$ & $2.5 \times 10^{-5}$ & $4.4 \times 10^{-5}$ \\
\hline & Labour & - & - & - & 1.75 & 1.21 \\
\hline \multirow[t]{3}{*}{ Transport } & Raw materials & $\begin{array}{l}\text { Ocean freighter and } \\
\text { Lorries } 20-40 \mathrm{t}(\mathrm{tkm})\end{array}$ & 158.07 & 62.28 & 3.03 & 2.05 \\
\hline & Final product & Lorry 40t (tkm) & 20.11 & 15.50 & 1.73 & 1.34 \\
\hline & Diaper wastes & Lorry $40 \mathrm{t}$ (tkm) & 2.02 & 1.56 & 4.22 & 3.26 \\
\hline \multirow{3}{*}{$\begin{array}{l}\text { Waste } \\
\text { management }\end{array}$} & Recycling & Packaging waste & 0.15 & 0.13 & 0.01 & 0.01 \\
\hline & Incineration & $\begin{array}{l}\text { Packaging and used } \\
\text { diapers }\end{array}$ & 15.36 & 11.86 & 2.94 & 2.29 \\
\hline & Landfilling & $\begin{array}{l}\text { Packaging and used } \\
\text { diapers }\end{array}$ & 25.00 & 19.29 & 0.47 & 0.36 \\
\hline
\end{tabular}

${ }^{a}$ NW: nonwoven; ADL: acquisition and distribution layer; ATB: air-through bonded layer; SAP: superabsorbent polymer; L\&S: lubricants and solvents.

2.1.4.1. Raw materials

The amount of raw materials in Table 2 corresponds to a typical diaper design for 6-12 month-old babies. The data for the raw materials include production losses, which account 
for $1 \%$ of the inputs. All the diaper material layers and components have been considered, with the exception of the fastening tapes of the back ears, the waist and leg elastics and the lotions, inks and dyes (optional elements). These materials represent less than $1 \%$ of the product weight and they are not affected by the glueless innovations (Mendoza et al., 2019). As can be seen in Table 2, the costs of the raw materials range from $€ 0.95 / \mathrm{kg}$ (e.g. cellulose pulp) to $€ 39 / \mathrm{kg}$ (e.g. frontal tape).

\subsubsection{Diaper manufacture}

The energy costs have been calculated considering the electricity consumption by the industrial equipment and the cost of electricity to industry in Italy. The latter corresponds to $€ 0.18 / \mathrm{kWh}$ (Eurostat, 2018b). Maintenance costs refer to periodic check-ups of equipment components, lubrication, replacement of parts and cleaning components (e.g. filters), based on the maintenance schedule for the machinery. Labour costs (€25/h-employee) are based on the time spent by the staff (six members) for loading and handling the raw materials as well as monitoring the equipment performance during the production shift. Diaper manufacturing costs do not include the development, installation, commissioning and waste management of the equipment due to confidentiality.

\subsubsection{Transport}

Raw materials are transported to distances from $50 \mathrm{~km}$ (e.g. nonwovens for the front and back ears) to 2,300 km (e.g. upper and lower tissues). The fluff pulp is shipped by ocean freighter over a distance of 9,250 km (from Georgia in USA to Livorno in Italy). The transport costs of the raw materials range from $€ 100$ to $€ 3,100$. This is equivalent to $€ 0.005$ and $€ 0.14$ per $\mathrm{kg}$ material transported. The transportation cost of the diapers from the manufacturing plant to households $(500 \mathrm{~km})$ is estimated at $€ 0.04 / \mathrm{kg}$. Finally, the cost of transport of the production and household wastes to waste management plants $(10 \mathrm{~km}$ and $100 \mathrm{~km}$, respectively) is equivalent to $0.105 € / \mathrm{kg}$, based on the data by ISPRA (2017) for undifferentiated urban waste.

\subsubsection{Waste management}

These costs refer to the management of used diapers in Italy. Waste recycling costs relate to the packaging waste produced in diaper manufacturing (Table 2). According to CONAi (2013), management of waste cardboard and plastic packaging costs $€ 22 / t$ and $€ 160 / t$, respectively. However, the recycled content of cardboard packaging is almost equivalent to the cardboard recycling rate in Italy (85\%) (FEFCO and Cepi, 2012). Consequently, no costs were allocated to cardboard recycling to avoid double counting. Thus, the cost of waste recycling corresponds only to the recycling of plastic film. This cost has been allocated by mass, considering the amount of packaging that is sent to recycling $(37 \%$, Table 2$)$.

Waste incineration and landfilling include production waste and the used diapers. It has been assumed that $38 \%$ of the weight of the diapers, $37 \%$ of plastic film and $7 \%$ of corrugated cardboard are incinerated with energy recovery. Thus, $62 \%$ of the diapers, $26 \%$ of plastic and $8 \%$ of cardboard packaging are sent to landfill. Municipal waste incineration in Italy is assumed to cost $€ 271 / \mathrm{t}$, including bottom and fly ash management and air pollution control (Hogg, 2002). The allocation of incineration costs by mass corresponds to $€ 4.1$ per 1,000 standard diapers and $€ 3.2$ per 1,000 glueless diapers. However, incineration of 1,000 used standard diapers generates $47 \mathrm{MJ}$ of process steam (thermal energy) and $16 \mathrm{MJ}$ of electricity, whereas glueless diapers produce $36 \mathrm{MJ}$ of process steam and $12 \mathrm{MJ}$ of electricity (Mendoza et al., 2019). Considering a price of $€ 0.18 / \mathrm{kWh}$ for electricity and $€ 0.033 / \mathrm{kWh}$ for natural gas (Eurostat, 2018c), the final cost of the incineration of 1,000 standard and glueless diapers has been determined at $€ 2.9$ and $€ 2.3$, respectively. 
Municipal waste landfilling in Italy costs $€ 19 / t$ (CEWEP, 2017). This cost has been allocated to the diapers considering the share (dry weight) that ends up in landfills, including packaging wastes.

\subsubsection{Annual production and consumption of diapers at different scales}

To determine the economic and environmental implications of the annual production and consumption of standard and glueless diapers, the data related to the production of 1,000 units per minute (presented in the previous sections), have been scaled up to the following levels: a P10 production platform, an average industrial plant (four P10 platforms), a country (Italy) and the EU. A single P10 platform is assumed to produce 225 million of diapers per year and an average industrial plant 900 million diapers (Mendoza et al. 2018). In Italy, 1.8 billion of disposable baby diapers were sold in 2016; at the EU level the sales reached 20.8 billion (Euromonitor International, 2015).

The raw materials used in diaper manufacturing have been assumed to cost the same in Italy and the EU due to a lack of data for the individual EU countries. The same assumption applies to the maintenance and labour costs. These assumptions represent a limitation of the study. However, given that the aim is to identify a general trend across the EU rather than distinguish between the costs in different countries for comparative purposes, these assumptions are considered sufficiently valid.

Each EU country has been considered to contribute to the cost of the electricity grid mix proportionally to their national diaper production volume (Mendoza et al., 2019). Accordingly, data from Euromonitor International (2015) on the production of tissue and hygiene products by the EU countries and Eurostat (2018b) electricity price statistics have been used. As a result, the 2016 price per $\mathrm{kWh}$ of electricity (non-household) consumption in the EU is estimated at $€ 0.14$.

The EU costs for the transportation of the raw materials have been assumed to be the same as for Italy (Table 2). The cost of transport of diapers from the factory gate to households is $€ 0.07 / \mathrm{kg}$ (De Jong et al. 2010). Collection and transportation of production and household wastes have been considered to be the same as for Italy (Table 2) due to a lack of data for the EU.

For estimating the costs of managing waste diapers in the EU, it is assumed that $49 \%$ of the used diapers are sent to incineration with energy recovery, $45 \%$ to landfill and $6 \%$ to incineration without energy recovery (Mendoza et al., 2019). It is also supposed that $37 \%$ of the plastic film and $83 \%$ of the cardboard packaging are sent to recycling, whereas $30 \%$ and $7 \%$, respectively, are incinerated. The remaining plastic film (34\%) and corrugated cardboard (10\%) are landfilled. The cost of plastic film recycling in the EU has been estimated at €296/t (WRAP 2016; Eurostat 2018d). As the recycled content of cardboard packaging is almost equivalent to the cardboard recycling share in the $\mathrm{EU}$, no cost has been allocated to the recycling of cardboard packaging.

The waste incineration costs in the EU are assumed at $€ 280 / \mathrm{t}$ (Hogg et al., 2002). Incineration of 1,000 standard diapers in the EU generates $5.6 \mathrm{kWh}$ of electricity and 16.9 $\mathrm{kWh}$ of process stream (Mendoza et al., 2019). For the glueless diapers, the corresponding values are $4.3 \mathrm{kWh}$ of electricity and $13 \mathrm{kWh}$ of process steam. The economic credits related to energy recovery during waste incineration have been calculated by considering the same electricity price as above (€0.14/kWh) and $€ 0.037 / \mathrm{kWh}$ for natural gas (non-household) (Eurostat, 2018c). The EU average cost of landfilling municipal solid waste is estimated at $€ 35.8 / t$ (CEWEP, 2017). For further details on the data at the EU level, see Table S1 in the Supporting Information (SI). 


\subsection{Eco-efficiency analysis}

Eco-efficiency can be defined as the delivery of competitively priced goods that satisfy human needs, while progressively reducing resource intensity and ecological impacts (WBCSD, 2006). Thus, eco-efficiency is fundamentally a ratio of some measure of economic value to some measure of environmental impact (Ehrenfeld, 2005). This premise has been used in the estimation of eco-efficiency of disposable diapers, as described next.

\subsubsection{Estimation of eco-efficiency indicators}

The eco-efficiency analysis of the standard and glueless diapers has been performed following the guidelines in the ISO 14045 standard (ISO, 2012). For this purpose, the LCC results obtained in this work have been combined with the LCA results reported previously by the authors (Mendoza et al. 2018). Accordingly, the environmental indicators considered are: abiotic depletion potential of elements $\left(\mathrm{ADP}_{\mathrm{e}}\right)$, abiotic depletion potential of fossil fuels $\left(\mathrm{ADP}_{\mathrm{f}}\right)$, acidification potential $(\mathrm{AP})$, eutrophication potential (EP), freshwater aquatic ecotoxicity potential (FAETP), global warming potential (GWP), human toxicity potential (HTP), marine aquatic ecotoxicity potential (MAETP), ozone layer depletion potential (ODP), photochemical oxidants creation potential (POCP) and terrestrial ecotoxicity potential (TETP). In addition, primary energy demand (PED), based on the net calorific value, is also considered.

The eco-efficiency of both types of diaper with respect to each of the above environmental impacts has been calculated as follows:

$$
E E_{i, d}=\frac{L C C_{d}}{E I_{i, d}} \quad(€ / \text { impact })
$$

where:

$E E_{i, d} \quad$ eco-efficiency with respect to environmental impact $i(€ /$ impact) for diaper type $d$ $L C C_{d} \quad$ life cycle costs of diaper type $d(€)$

$E l_{i, d} \quad$ life cycle environmental impact $i$ for diaper type $d$ (different units as in LCA)

$d \quad$ diaper type (standard or glueless).

The estimated eco-efficiency indicators $E E_{i, d}$ have then been normalised and aggregated into a single eco-efficiency score for each diaper type to enable their easier comparison. Normalisation has been carried out based on the maximum values of $E E_{i, d}($ ISO, 2012). This means that the diaper with the maximum eco-efficiency $E E_{i, d}$ for a particular impact is given a value of 1 , whereas the other product has the normalised value equal to the ratio of its eco-efficiency $E E_{i, d}$ and the maximum eco-efficiency. This is represented by the following equation:

$$
E E N_{i, d}=\frac{E E_{i, d \text { min }}}{E E_{i, d \text { max }}}
$$

where:

$$
\begin{array}{ll}
E E N_{i, d} & \text { normalised eco-efficiency of diaper type } d(-) \\
E E_{i, d} \min & \begin{array}{l}
\text { minimum (lower) eco-efficiency between the two types of diaper for } \\
\text { environmental impact } i(€ / \text { impact) }
\end{array} \\
E E_{i, d} \text { max } & \begin{array}{l}
\text { maximum (higher) eco-efficiency between the two types of diaper for } \\
\text { environmental impact } i(€ / \text { impact). }
\end{array}
\end{array}
$$

The normalised eco-efficiency indicators have then been aggregated into a single ecoefficiency indicator assuming their equal importance: 
$E E_{d}=\sum_{i}^{n} \frac{E E N_{i, d}}{n}$

where:

$E E_{d} \quad$ overall aggregated eco-efficiency of diaper type $d(-)$

$n \quad$ number of eco-efficiency indicators (= number of environmental impacts considered in LCA).

Thus, as eq. (4) indicates, the aggregated eco-efficiency scores represent the average values of the normalised eco-efficiency indicators.

\section{Results and discussion}

\subsection{Life cycle costing}

\subsubsection{Life cycle costs of 1,000 diapers}

The LCC of 1,000 standard and glueless diapers are estimated at $€ 106.3$ and $€ 95.1$, respectively (Figure 3 ). Thus, the glueless diapers are $10.6 \%$ more cost-efficient than the conventional design. This is largely due to their greater material efficiency, with a saving in materials use of $9.2 \mathrm{~kg} / 1,000$ diapers. This also has a knock-on effect on transport and packaging.

The raw materials determine over $85 \%$ of the total cost of both diapers, followed by the transport and waste management stages, with $7 \%$ and $3 \%$, respectively. The manufacturing process contributes only $2 \%$ to the total costs. Consequently, the raw materials stand out as the most significant hot-spot for both products.

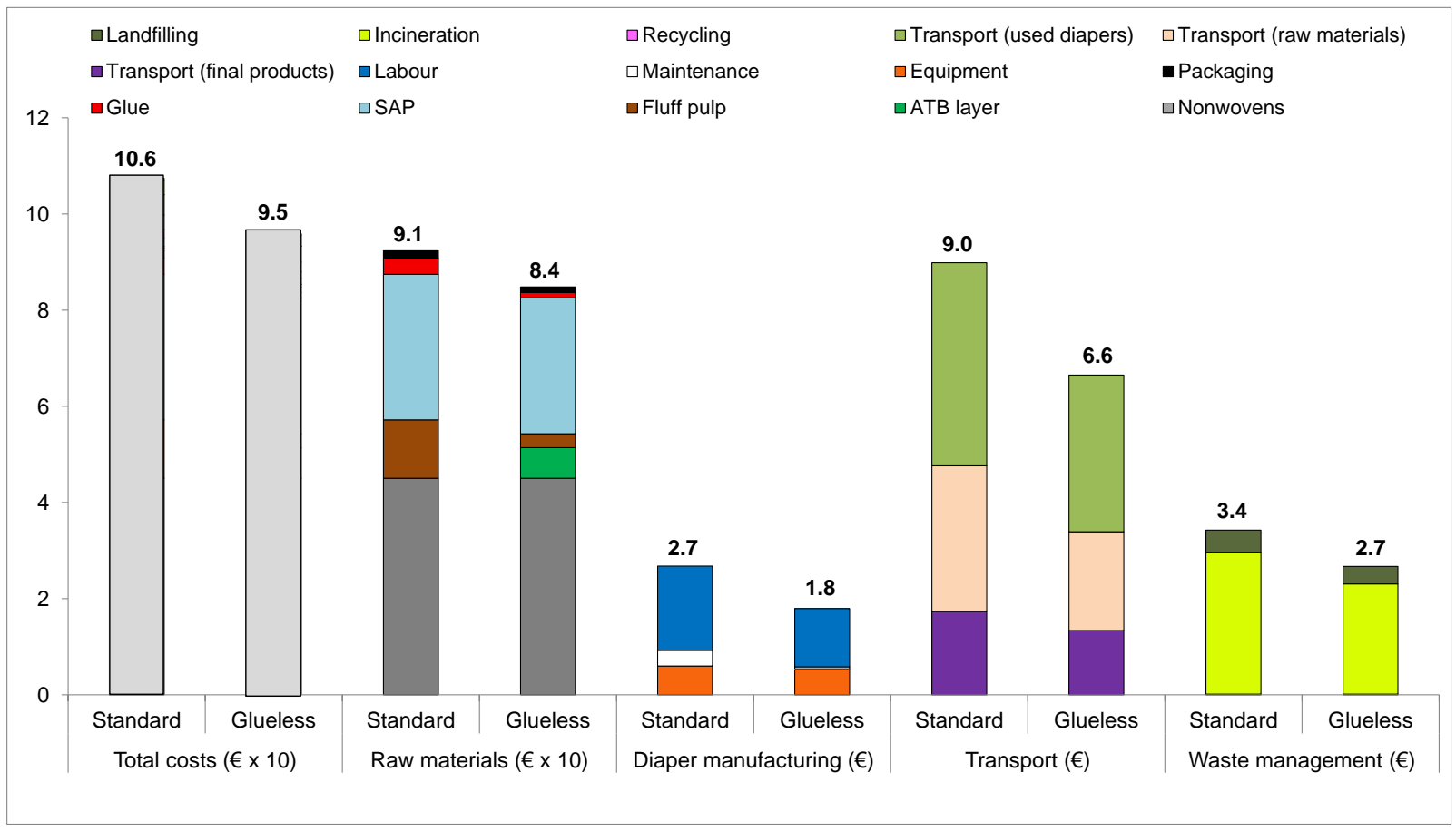

Figure 3 Total life cycle costs of 1,000 standard and glueless diapers showing contribution of different life cycle stages

(ATB: air-trough bonded nonwoven; SAP: superabsorbent polymers. Packaging: corrugated cardboard and plastic film. Nonwovens: cuffs, topsheet, ADL, upper and lower tissues, backsheets, front and back ears and elastics). 
Looking at the individual life cycle stages, the raw material costs for the glueless diapers are $8 \%(€ 7.26 / 1,000$ diapers) lower than for the standard product. This saving is largely due to the reduction in the fluff pulp content (Table 2), which cuts the cost by $€ 9.23 / 1,000$ diapers, with a further savings of $€ 2.24$ due to the glue removal, $€ 2.02$ from a lower use of SAP and $€ 0.1$ due to reduced packaging. However, these savings are reduced by the air-trough bonded (ATB) nonwoven layer used to build the absorbent core which adds $€ 6.33$ to the costs of glueless diapers.

The higher material efficiency of glueless diapers also reduces transport costs by $26 \%$ (€2.34/1,000 diapers). The transportation of the raw materials to the manufacturing plant and of used products to waste management facilities is cut by $€ 0.98$ in each case. An additional saving of $€ 0.40 / 1,000$ diapers is achieved in the transportation of diapers to households.

The cost savings related to the use of alternative bonding technologies in glueless diaper manufacturing ( $€ 0.88 / 1,000$ diapers) are related to the reduction in the labour costs. The removal of glue applicators and chillers (Table 2) reduces the need to clean the machinery to avoid glue contamination between production shifts. It also prolongs operating times, increasing production efficiencies and reducing the workload of operators. The resulting reduction in labour costs accounts for almost $61 \%$ (€0.54/1,000 diapers) of the cost savings. Lower maintenance requirements and energy consumption by the manufacturing equipment contribute to the savings of $32 \%$ (€0.29) and $7 \%$ (€0.06), respectively.

Standard diaper manufacturing consumes $3.35 \mathrm{kWh} / 1,000$ diapers of electricity, which is equivalent to a cost of $€ 0.60$ (Table 2). The electricity consumption for glueless diapers is $3.02 \mathrm{kWh} / 1,000$ diapers, a reduction of $9.8 \%$. The vacuum system and the motors are the most energy intensive equipment, using $84 \%$ (standard production) and $94 \%$ (glueless production) of electricity. Consequently, they determine an equivalent share of the electricity costs of diaper manufacturing. However, the cost associated with the maintenance of the vacuum system and the motors is negligible compared to the maintenance costs of the glue applicators (Table 2). The maintenance of glue applicators in standard diaper manufacturing determines up to $98 \%$ ( $€ 0.32 / 1,000$ diapers) of the total maintenance costs. Nevertheless, the use of alternative bonding technologies (ultrasonic and thermo-mechanical units) in glueless diaper manufacturing reduces the operating and maintenance costs by $47 \%$ $(€ 0.02 / 1,000$ diapers) and $89 \%$ ( $€ 0.28 / 1,000$ diapers), respectively. The removal of the pneumatic unit generates an additional saving of $€ 0.05 / 1,000$ diapers.

The higher material efficiency of the glueless diapers also reduces waste management costs by $22 \%$ ( $€ 0.76 / 1,000$ diapers). The costs of incineration and landfilling are by $€ 0.65$ and $€ 0.11$ lower, respectively, than those for the standard product. The recycling costs of packaging are also $2.7 \%$ lower.

According to these findings, the implementation of glueless innovations in manufacturing reduces the LCC of diapers by $€ 11.2 / 1,000$ units. This represents a significant annual saving considering the large volume of diapers produced and consumed globally, as demonstrated in the next section.

\subsubsection{Life cycle costs of diapers at different scales}

The findings in Table 3 demonstrate that the manufacture of glueless diapers can cut the annual costs from $€ 2.5 \mathrm{~m}$ for a single P10 production platform to almost $€ 250 \mathrm{~m}$ at the EU level. The latter is equivalent to the average net earnings of around 14,360 single people in the EU (Eurostat 2017). 
Table 3 Annual life cycle costs of standard and glueless diapers for different scales of production and consumption.

\begin{tabular}{lllll}
\hline Scale & $\begin{array}{l}\text { Annual production } \\
\text { (million units) }\end{array}$ & $\begin{array}{l}\text { Standard diapers } \\
\text { (million } € \text { ) }\end{array}$ & $\begin{array}{l}\text { Glueless diapers } \\
\text { (million } € \text { ) }\end{array}$ & $\begin{array}{l}\text { Glueless } \\
\text { savings } \\
\text { (million } € \text { ) }\end{array}$ \\
\hline P10 production platform & $225^{\mathrm{a}}$ & 23.9 & 21.4 & 2.5 \\
Average industrial plant & $900^{\mathrm{b}}$ & 95.7 & 85.6 & 10.1 \\
Italy & $1,797.7^{\mathrm{c}}$ & 191.2 & 171.0 & 20.2 \\
EU & $20,817.5^{\mathrm{c}}$ & $2,274.8$ & $2,026.3$ & 248.6 \\
\hline
\end{tabular}

${ }^{\mathrm{a}}$ Two production cycles of $15 \mathrm{~h}$ per day during 250 working days (Mendoza et al. 2018).

${ }^{\mathrm{b}}$ Four P10 production platforms with the same operating conditions as a single P10 platform.

${ }^{c}$ Euromonitor International (2015).

The reduction in electricity consumption, maintenance and labour requirements reduces the annual costs by around $€ 198,400$ for a single P10 platform and $€ 794,000$ for an average industrial plant (with four P10 platforms). At the level of Italy, the savings go up to $€ 1.6 \mathrm{~m}$ and at the EU level to $€ 18.1 \mathrm{~m}$. Likewise, the reduction of $0.63 \mathrm{~kg}$ of glue per 1,000 diapers (Table 2) cuts the raw material costs by $€ 505,000$ per production platform and by $€ 2 m$ for an average production plant. These savings scale up to $€ 4 \mathrm{~m}$ for Italy and $€ 47 \mathrm{~m}$ for the EU.

Thus, these findings demonstrate that small improvements in resource efficiency of these products can lead to significant cost savings, increasing their eco-efficiency. The latter is analysed in the following section.

\subsection{Eco-efficiency of diapers}

Based on the findings by Mendoza et al. (2019), and as shown in Figure 4, glueless diapers have $1.1 \%-67 \%$ lower environmental impacts than the standard product; the GWP is $10.4 \%$ lower, saving $9.5 \mathrm{~kg} \mathrm{CO} 2$ eq./1,000 diapers. Focusing on the latter as an example and looking at the annual savings, this ranges from $2.1 \mathrm{kt}$ of $\mathrm{CO}_{2}$ eq. per $\mathrm{P} 10$ platform to $184.4 \mathrm{kt}$ at the EU level (Table 4). The glue removal alone saves $56,000 \mathrm{t} \mathrm{CO}_{2}$ eq. For details on the other impacts, see Mendoza et al. (2019).

It can also be seen in Figure 4 that the contributions of different life cycle stages to the costs and impacts follow a similar trend. The raw materials represent the most significant hot-spot for both diapers. Hence, the environmental and cost savings for the glueless diapers are mainly due to the reduced amount of raw materials, particularly fluff pulp, SAP and glue (Table 2), which in turn reduces the impacts and cots of the other life cycle stages.

Table 4 Savings in the annual global warming potential for the glueless diapers relative to the standard type for different scales of production and consumption.

\begin{tabular}{lllll}
\hline Scale & $\begin{array}{l}\text { Annual } \\
\text { production } \\
\text { (million units) }\end{array}$ & $\begin{array}{l}\text { Standard diapers } \\
\text { (kt } \mathbf{C O}_{\mathbf{2}} \text { eq.) }\end{array}$ & $\begin{array}{l}\text { Glueless diapers } \\
\text { (kt } \mathbf{C O}_{\mathbf{2}} \text { eq.) }\end{array}$ & $\begin{array}{l}\text { Glueless } \\
\text { savings } \\
\text { (kt } \mathbf{C O}_{\mathbf{2}} \text { eq.) }\end{array}$ \\
\hline P10 production platform & $225^{\mathrm{a}}$ & 20.6 & 18.5 & 2.1 \\
Average industrial plant & $900^{\mathrm{b}}$ & 82.4 & 73.8 & 8.6 \\
Italy & $1,797.7^{\mathrm{c}}$ & 164.5 & 147.4 & 17.1 \\
EU & $20,817.5^{\mathrm{c}}$ & $1,847.6$ & $1,663.2$ & 184.4 \\
\hline
\end{tabular}

\footnotetext{
${ }^{a}$ Two production cycles of $15 \mathrm{~h}$ per day during 250 working days (Mendoza et al. 2018).

${ }^{\mathrm{b}}$ Four P10 production platforms with the same operating conditions as a single P10 platform.

${ }^{c}$ Euromonitor International (2015).
} 


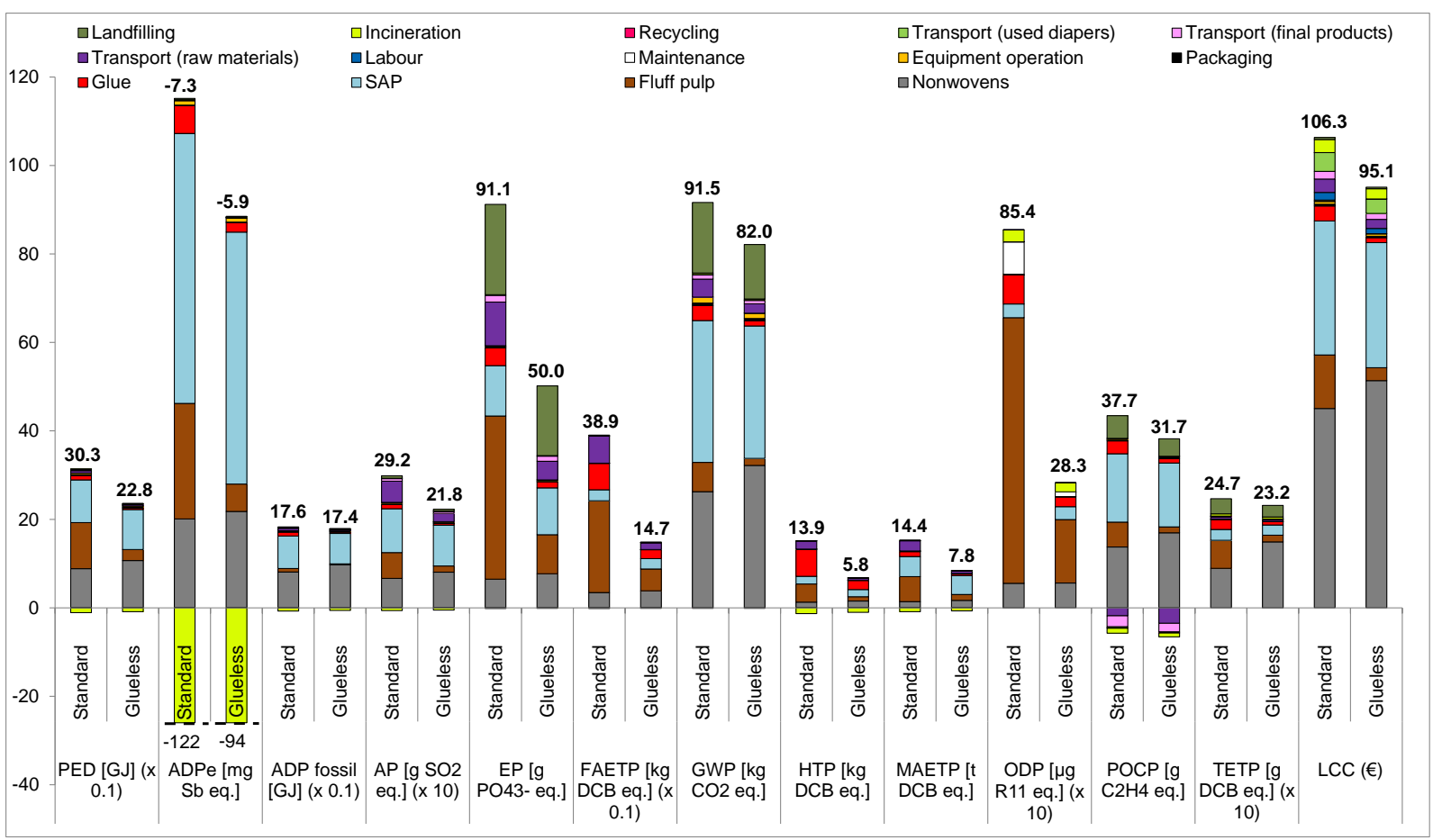

Figure 4 Life cycle environmental impacts of 1,000 standard and glueless diapers (based on Mendoza et al. (2019)).

(Some impacts have been scaled to fit; to obtain the original values, multiply by the factors shown on the x-axis where relevant. Packaging: corrugated cardboard and plastic film. Nonwovens: cuffs, topsheet, acquisition and distribution layer, upper and lower tissues, backsheets, front and back ears and elastics. PED: primary energy demand, $A D P_{e}$ : abiotic depletion potential of elements, $A D P_{f}$ : abiotic depletion potential of fossil resources, $A P$ : acidification potential, EP: eutrophication potential, GWP: global warming potential, HTP: human toxicity potential, MAETP: marine aquatic ecotoxicity potential, FAETP: freshwater aquatic ecotoxicity potential, ODP: ozone depletion potential, POCP: photochemical oxidants creation potential, TETP: terrestrial ecotoxicity potential; LCC: life cycle costs; DCB: dichlorobenzene; ATB: air-trough bonded nonwoven; SAP: superabsorbent polymers).

Combining the life cycle costs and impacts into the eco-efficiency indicators in Figure 5, estimated using eq. (2) and expressed in $€ /$ impact per 1,000 diapers, indicates that the glueless diapers are $7 \%$ (POCP) to $170 \%$ (ODP) more eco-efficient than the standard product across most impact categories. The high efficiency for ODP is related to the lower use of solvents to clean the glue applicators between production shifts in glueless diaper manufacturing. The next highest eco-efficiency value is found for FAETP, which is $136 \%$ higher for the glueless diapers because of the notable reduction in the fluff pulp for the absorbent core.

The only exceptions to these trends are $\mathrm{ADP}_{\mathrm{f}}$ and TETP for which the standard diapers are a better option by $9.6 \%$ and $4.7 \%$, respectively. This is despite these two impacts being lower for the glueless diapers (Figure 4). The reason for this is that the relative cost savings are higher than the savings in these two impacts, leading to a reduced eco-efficiency compared to the standard diapers. A similar but a lesser effect is noticed for the ecoefficiency related to the GWP, resulting in the values for this category being equal for both diaper products. 


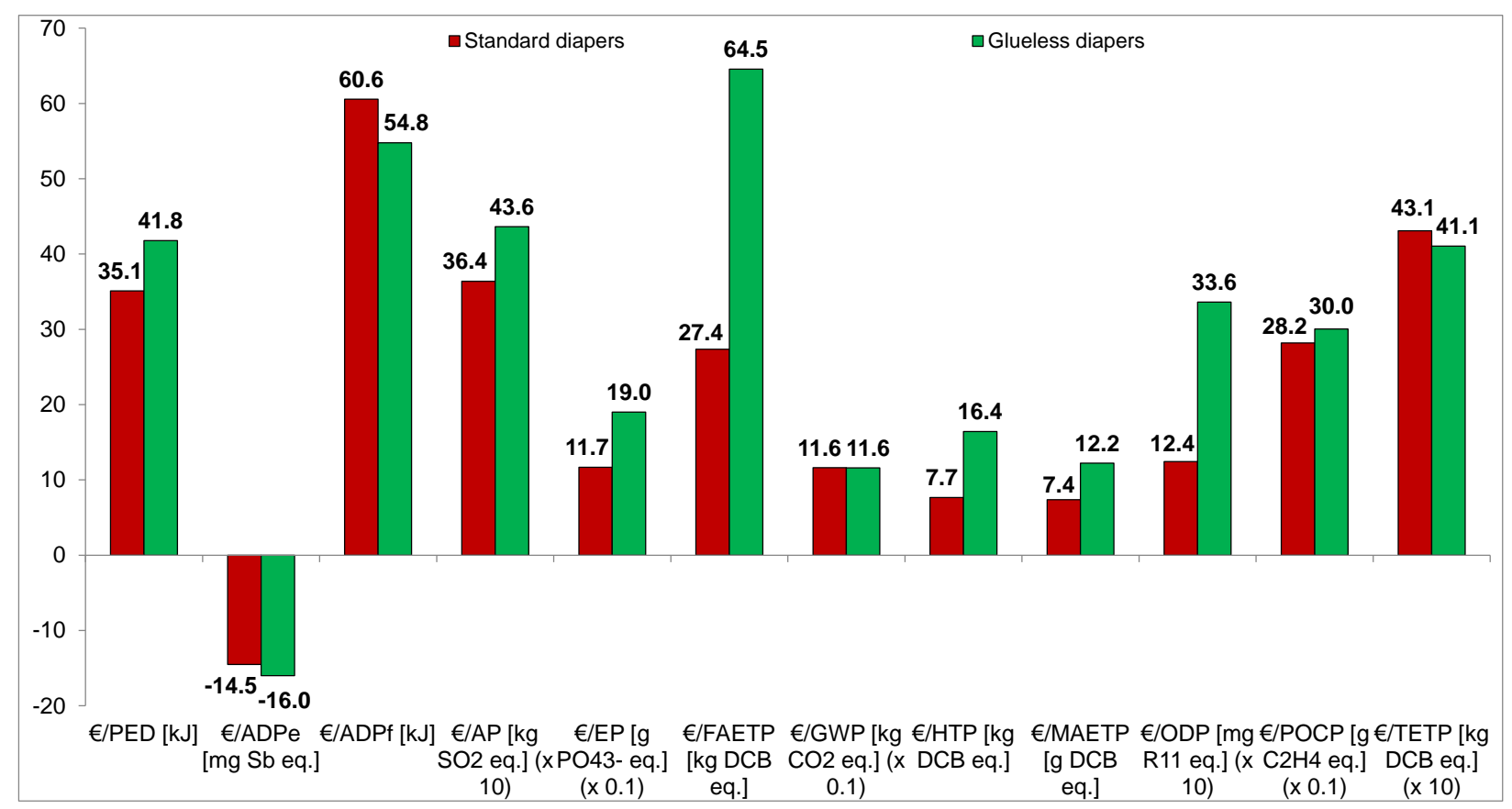

Figure 5 Eco-efficiency of 1,000 standard and glueless diapers.

(Some eco-efficiency indicators have been scaled to fit; to obtain the original values, multiply by the factors shown on the $x$-axis where relevant. For the impacts nomenclature, see Figure 4).

However, these results should not be taken out of context - the lower or equal eco-efficiency of the glueless relative to the standard diapers does not mean that there are no environmental or cost savings. For instance, although their eco-efficiency with respect to GWP is equal, glueless diapers have lower both GHG emissions and costs (Table 3 and Table 4). Therefore, care is needed in interpreting eco-efficiency results to avoid ill-informed or wrong conclusions.

Normalising and aggregating the eco-efficiency indicators into a single score (eqns. (3) and (4)) shows that glueless diapers are $32 \%$ more efficient than the standard product, with their respective overall eco-efficiency scores related to the environmental impacts equal to 0.99 and 0.75 (Figure 6). For the normalised impacts by impact category (disaggregated), see Figure S1 in the SI.

Figure 6 also shows the eco-efficiency analysis with respect to resource and waste efficiency. As can be observed, glueless and standard diapers have a similar eco-efficiency with respect to energy (electricity) consumption in the manufacturing process. However, glueless manufacturing has a $9.6 \%$ lower actual electricity consumption (Table 2). At the EU level, this is equivalent to a saving of $6.8 \mathrm{GWh}$ and cost reduction of nearly $€ 1$ million. This further demonstrates the need for considering the actual (absolute) values rather than relying on the eco-efficiency indices alone.

With respect to the use of material resources, glueless diapers are $15 \%$ more eco-efficient than the standard variety. The same difference in favour of the glueless product is found for waste generation because it is directly related to the material inputs (Figure 6). Based on the data in Table 2-Table 4, glueless manufacturing reduces the consumption of raw materials by $2100 \mathrm{t}$ per production platform and $192,200 \mathrm{t}$ at the EU level, with the respective cost reductions of $€ 1.6 \mathrm{~m}$ and $€ 151 \mathrm{~m}$. The reduction in waste saves further $€ 0.17 \mathrm{~m}$ to $€ 25.7 \mathrm{~m}$. 


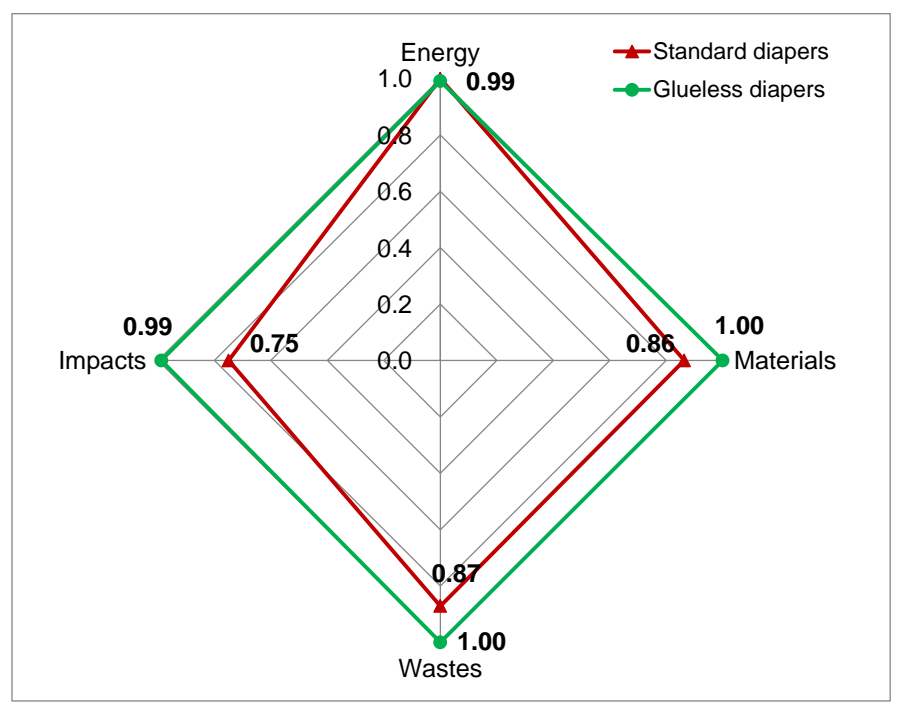

Figure 6 Normalised eco-efficiency indicators for standard and glueless diapers.

\subsection{Disposable baby diapers and the circular economy}

The results of this work have demonstrated that glueless diaper manufacturing can lead to significant resource, environmental and cost savings at the EU level and, by implication, globally. Nevertheless, product light-weighting (e.g. material optimisation of the absorbent core through eco-design) and cleaner production (e.g. use of alternative bonding technologies) will not resolve the critical underlying issue of linear material consumption and waste generation associated with the diapers.

Considering the annual consumption of disposable baby diapers in the EU ( 21 billion), the use of glueless diapers in substitution of standard products would still lead to the consumption of $652,000 \mathrm{t}$ of raw materials that would end up in waste incineration plants and landfills. Although this is by $192,000 \mathrm{t}$ lower than for the standard diapers, disposable diapers follow a linear economy based on take, make, use and dispose as opposed to a circular economy where products are reused and recycled in closed-loop systems (EMF, 2015). Thus, product light-weighting and cleaner production should be complemented with circular economy strategies to maximise the overall resource efficiency and sustainability of the diaper industry. These strategies can include the design of reusable products, the use of bio-materials (e.g. bamboo and corn), post-consumer waste recycling and composting of used diapers as well as development of novel business models. However, none of these strategies is exempt from technical, socio-economic and environmental challenges, as discussed below.

\subsubsection{Reusable baby diapers}

Reusable (cloth) diapers can reduce material consumption and waste generation. However, they consume energy, water and detergents for washing and drying with the corresponding waterborne emissions and other environmental impacts (Environment Agency, 2008). Likewise, reusable diapers have disposable inner layers (inserts) that must be removed and disposed of after each use. Although the inserts can be flushable and compostable, they are not compatible with all sewage systems and can cause blockages. They can also lead to increased water usage from additional flushing in households. The inserts can also have a potentially negative effect on the final effluent from municipal wastewater treatment plants because part of the material does not settle out during the process (Circle Economy, 2015). For this reason, there is a consensus among LCA practitioners (Environment Agency, 2008; O'Brien et al., 2009) that neither of the two alternatives - reusable and disposable diapers is environmentally better than the other but their environmental hot-spots are concentrated in different life cycle stages. 


\subsubsection{Bio-based baby diapers}

Focusing on the use of bio-materials in diaper manufacturing, the LCA literature (e.g. Clancy et al., 2013; Mirabella et al., 2013) suggest that some impacts can be lower for bio-based diapers, such as human toxicity, freshwater eutrophication and marine ecotoxicity. However, the use of bio-materials leads to greater water depletion, land requirements and terrestrial ecotoxicity. The environmental impacts of bio-based diapers are highly determined by the use of non-renewable energy sources and intensive agricultural practices in the production of bio-materials. Therefore, Mirabella et al. (2013) suggests that cleaner production of biomaterials, along with the implementation of efficient composting systems for used diapers, is essential for improving their environmental performance. Likewise, Gontia and Janssen (2016) show that the alternative production of bio-based SAP from sugars present in pulpmill side streams can reduce the emission of greenhouse gasses but at the expense of other environmental impacts compared to fossil-based SAP. Thus, further efforts should concentrate on the development of a high-yield yeast for the fermentation of sugars, complemented with the implementation of low-energy biochemical processes (Gontia and Janssen, 2016).

\subsubsection{Composting of diapers}

According to Colon et al. (2013), a significant amount of organic matter can be recovered through composting of the source-separated organic municipal solid waste, including biodegradable diapers. Although a well-implemented composting system for bio-based diapers can produce fertilisers for use in agriculture, new land area would be required for the processing of bio-based materials with a risk of land use change (Hakala et al., 1997). Composting of conventional diapers with organic municipal solid waste has no negative effects on the technical and biological performance of the process. However, the resulting compost can have slightly elevated concentrations of zinc (Colon et al., 2010) and pH values (Espinosa-Valdemar et al., 2014). Consequently, large amounts of conventional diapers mixed with organic municipal solid waste can affect the quality of the compost. Additionally, the behaviour of superabsorbent polymers in soils is still unknown due to long degradation times. This could lead to unforeseen harmful effects on humans and the environment (Colon et al., 2010). Therefore, according to EDANA (2008), composting of used diapers comingled with other organic household waste should not be practised unless they could undergo, for instance, a mechanical-biological treatment to separate them into different (biodegradable and synthetic) material fractions, which can then undergo specific treatments (recycling, aerobic or anaerobic digestion). Thus, a comprehensive environmental and socio-economic assessment should be performed to validate the feasibility of this waste management alternative.

\subsubsection{Recycling of diapers}

Post-consumer waste recycling processes for material recovery of AHPs, including disposable baby diapers, have already been implemented and commercialised (Arena et al., 2016). This includes the Knowaste facility in the UK (Deloitte, 2011) and the Fater facility in Italy (Fater, 2015). The former has a capacity of 36,000t/year (Deloitte, 2011). The recycling of $1 \mathrm{t}$ of used AHPs can yield $75 \mathrm{~kg}$ of sterilised plastic, $75 \mathrm{~kg}$ of SAP and $150 \mathrm{~kg}$ of cellulose that can be reused as secondary materials in some production processes, such as furniture, paper, cables protection, polymers and fertilisers (Fater, 2015). Once the organic and synthetic fractions are separated, plastics can be recovered using the cellulose fraction (e.g. fluff pulp) to produce energy (steam) for sterilisation (Arena et al., 2016). Therefore, AHP wastes can be efficiently recycled without external energy inputs. However, currently there is a low market penetration of AHP recycling technologies and some of these waste management plants are still under pilot testing. Likewise, there is a high level of uncertainty about the marketability and acceptability of recycled products. Further, the economic feasibility of the recycling process might be constrained by higher costs related to collection and sorting as individual waste fractions (EDANA, 2008). 


\subsubsection{Circular economy business models}

Based on the information provided above, it could be argued that further product lightweighting and cleaner production remain the most promising options in the short term for improving the environmental and cost efficiency of disposable diapers, until the challenges discussed above can be overcome (Cordella et al., 2015; Mendoza et al., 2019). Alternatively, creative innovations aimed at supporting the development of new circular economy business models for baby diapers can also be explored. Business model innovations through the application of circular economy principles can help address resource efficiency and other sustainability challenges from a more strategic and systemic perspective, leading to greater socio-economic and environmental benefits in the long term (Llic et al., 2018).

For example, the DYCLE project (DYCLE, 2018) is developing a new business model for the diaper industry, which it is not only about substituting one type of diaper by another but about changing the way businesses operate through the application of natured-inspired creative solutions. DYCLE offers $100 \%$ compostable diapers (produced locally) for free, through a forward and reverse collection system. In this system, parents collect new diapers and drop used diapers in a pre-defined place. Used diapers are blended with charcoal, kitchen waste and fungus to be converted into black earth (rich soil) by using the terra-preta method (DYCLE, 2018). The resulting soil substrate can be used for fruit trees and plants. Fruit harvested from the trees could be used for baby food and juice production in order to close the nutrients and material cycle of baby diapers.

This example demonstrates that there is a potential to build successful circular economy and sustainable business models in the diaper industry. The use of nature-inspired analytical approaches in problem-solving, such as biomimicry (Benyus, 2002), cradle to cradle (McDonough and Braungart, 2003) and industrial ecology (Graedel and Allenby, 2006) could bring relevant insights for further innovation in this sector. Likewise, the use of holistic methodological frameworks integrating eco-design thinking and scenario analysis (Mendoza et al., 2017) can help identify suitable circular economy pathways for more resource-efficient and sustainable businesses.

\subsection{Implications for different actors}

This section discusses the potential implications of this research for manufacturers, policy makers, consumers and the researcher community.

\subsubsection{Implications for manufacturers}

This research has demonstrated that diaper manufacturers can increase their profits notably while reducing their resource intensity and environmental impacts as a result of the material and energy optimisation of the production chain. Likewise, fossil-based glue has a high human toxicity potential (Figure 4). Thus, its removal from some production modules and diaper parts (Table 1) reduces the risks to human health for both workers and babies. This can be considered an exemplary action towards social responsibility.

It is also worth noting that the resource, environmental and economic benefits identified here exclude the savings related to the purchase and management of ultrasonic and thermomechanical equipment in substitution of the gluing system (Section 2.1.4) - the former is less expensive to purchase, operate and manage over time.

Furthermore, the glueless innovations can be adapted for implementation in the manufacture of other AHPs, such as feminine sanitary pads and adult incontinence diapers. Accordingly, the implementation of these innovations across the AHP industry could bring significant resource, economic and environmental savings globally. The outcomes of this research could also be used as a baseline to support the development of further R\&D projects by 
manufacturers, who could be well-positioned to receive incentives from the European Commission that reward business investments and innovations in resource efficient and cleaner production (EU, 2010; EC, 2011).

\subsubsection{Implications for policy makers}

A wider deployment of glueless innovations across European manufacturers would contribute actively to delivering the EU resource efficiency agenda, helping to achieve the energy and climate goals beyond 2020 (EC, 2011). For instance, saving over 184,000 t of $\mathrm{CO}_{2}$ eq. annually by implementing glueless innovations in just five unit processes of the diaper manufacturing chain would be equivalent to cutting by $8 \%$ the annual GHG emissions of a country of the size of Malta (Eurostat, 2018e).

According to EC (2011), the transition to a green and low-carbon economy requires significant innovations, from incremental changes (e.g. glueless innovations) to major technological breakthroughs. The EU could facilitate the deployment of glueless innovations through the development of new cleaner-production policies encouraging, through incentives and other regulatory mechanisms, a transition to alternative bonding processes and manufacturing systems.

One important regulatory tool already in place is the EU Ecolabel for AHPs (EC, 2014b). This Ecolabel sets rigorous life cycle ecological criteria for baby diapers, including the sourcing, processing and treatment of raw materials. For adhesives, the use of certain chemicals, such as colophony resins, formaldehyde or some types of phthalates (e.g. diisobutyl and diisononyl) is banned, unless they are present in quite low concentrations (e.g. $<100-250$ ppm). However, hot-melt adhesives are exempt from this requirement.

The results of this research have demonstrated that hot-melt glue used to manufacture diapers has a high human toxicity potential, also contributing to other environmental impacts (Figure 4). Thus, the European Commission should revise the AHP Ecolabel with the purpose of setting more restrictive rules for the use of glues in the AHP industry. Rather than encouraging the use of less toxic adhesives, promoting the removal of glue would be a much more sustainable course of action. In addition, although the amount of glue used per diaper is small ( $<1 \mathrm{~g}$ per diaper), its elimination would lead to significant resource, environmental and economic savings globally (Table 3 and Table 4) due to the vast amount of diapers produced annually.

\subsubsection{Implications for consumers}

According to the EC (2011), accurate and clear environmental information, based on lifecycle impacts and economic costs of resource use, is needed to help guide consumption decisions and stimulate companies to keep innovating to deliver more sustainable products. Thus, the removal of glue from diapers, as long as it is adequately communicated, could help to increase consumer awareness and guide purchasing decisions. For example, if consumers are aware that glueless diapers have a reduced human toxicity potential, they may be more interested in choosing these over the standard diapers.

The final price of glueless diapers could not be determined due to confidentiality but it can be assumed that their retail price would not be much higher than the conventional products, particularly since glueless diaper manufacturing is less costly than the conventional process (Table 3). This could also help to encourage consumers to select glueless diapers and, potentially, other AHPs produced in a similar way.

\subsubsection{Implications for the research community}

One of the major limitations for carrying out comprehensive and meaningful sustainability studies is the lack of industrial data. For instance, some published LCA papers on baby diapers (e.g. Weisbrod and Van Hoof 2012) do not provide inventory data on materials 
composition due to the risk of formulation disclosure to competitors. This limits the ability of LCA practitioners to replicate the calculations and develop further studies on the topic.

Likewise, the European Disposables and Nonwovens Association (EDANA) has been carrying out LCA and economic studies since 1992 (EDANA, 2015). However, the life cycle inventories of nonwoven materials and diaper designs are not publicly available due to confidentiality and only EDANA members have access to them. Thus, this study is the first to publish both LCA and LCC data for disposable baby diapers using up-to-date industrial data. The inventories can be used by other researchers to replicate the results and develop new studies on the topic. This research could also be used as a baseline to develop a wider life cycle sustainability assessment by integrating social indicators with the economic and environmental data. This has not been covered by the scientific community yet. However, this requires cooperation from nonwoven and diaper producers, including EDANA.

\section{Conclusions}

This paper has presented the first comprehensive life cycle cost and eco-efficiency analysis of eco-design and cleaner production of disposable baby diapers, involving optimised absorbent core and use of alternative bonding technologies instead of glue.

The results show that the "glueless" innovations can cut the life cycle costs by $11 \%$ compared to standard diaper manufacturing. They also reduce the environmental impacts by up to $67 \%$. Overall, glueless diapers have a $32 \%$ higher eco-efficiency than the standard products, ranging from $7 \%-170 \%$ depending on the indicator considered. Consequently, glueless diaper manufacturing can lead to significant resource, environmental and cost savings due to the large volume of disposable baby diapers consumed globally. At the EU level, glueless diapers could save annually up to 192,000 t of materials (and wastes), 6.7 GWh of electricity, 4.3 TWh of primary energy, $184,000 \mathrm{t}$ of $\mathrm{CO}_{2}$ eq. and $€ 250$ million. A large share of these savings is due to the higher material efficiency of the glueless diapers.

It is worth noting that the glueless innovations are not unique for application in the diaper industry. They could be adapted for implementation in the manufacture of other absorbent hygiene products, including feminine sanitary pads and adult incontinence products. Thus, the implementation of glueless innovations across the whole AHP industry could bring significant resource, economic and environmental savings globally.

Likewise, insights from this project could be useful to stimulate innovation in other sectors where bonding processes play an important role, including the packaging, clothing and furniture industries. This could in turn lead to major benefits for the EU manufacturing industry. However, the technical feasibility and economic implications of this industrial transition should be analysed first.

Nevertheless, product light-weighting and cleaner production alone will not resolve the issue of linear material consumption and waste generation associated with the use of AHPs. Likewise, alternative options, such as use of bio-materials in AHP production, recycling and composting of waste AHPs or use of the cloth alternatives, also face various challenges, including burden shifting. Therefore, this calls for creative approaches in the design and development of novel circular economy business models and product-service solutions. In this process, it is also essential to use holistic analytical tools and indicators able to support system thinking in sustainability decision making. For instance, this study has demonstrated that the use of eco-efficiency indicators decontextualised from the LCC and LCA results could be misleading. The authors consider that the application of natured-inspired circular economy approaches would not only bring novelty in the development of sustainabilityoriented studies for the absorbent hygiene industry as a whole, but also provide relevant insights for future industrial innovations and development of strategic corporate sustainability plans. 


\section{Acknowledgements}

The authors would like to thank the European Commission for the financial support received to develop the LIFE12 ENV/IT/000423 project entitled "Petrol based Glue and Energy consumption reduction in diapers production processes". The authors would like also to acknowledge the whole glueless team from Fameccanica.Data SpA for their collaboration and technical support in the research.

\section{References}

Arena, U., Ardolino, F., Di Gregorio, F., 2016. Technological, environmental and social aspects of a recycling process of post-consumer absorbent hygiene products. J. Clean. Prod. 127, 289-301.

Benyus, J. 1997. Biomimicry: Innovation inspired by nature. William Morrow. New York.

CEWEP, 2017. Landfill taxes and bans overview for municipal solid wastes. Confederation of European Waste-to-Energy Plants (CEWEP). http://www.cewep.eu/wpcontent/uploads/2017/12/Landfill-taxes-and-bans-overview.pdf.

Circle Economy, 2015. Designers in a Circular Economy. http://gruener-hering.de/wpcontent/uploads/2017/07/Whitepaper-Designers-in-a-circular-economy.pdf.

Clancy, G., Fröling, M., Svanström, M., 2013. Changing from petroleum to wood-based materials: critical review of how product sustainability characteristics can be assessed and compared. J. Clean. Prod. 39, 372-385.

Colon, J., Ruggieri, L., Sanchez, A., Gonzalez, A., Puig, I., 2010. Possibilities of composting disposable diapers with municipal solid wastes. Waste Manage. Res. 29(3), 249-259.

Colon, J., Mestre-Montserrat, M., Puig-Ventosa, I., Sanche, A., 2013. Performance of compostable baby used diapers in the composting process with the organic fraction of municipal solid waste. Waste Manage. 33(5), 1097-1103.

CONEi, 2013. Packaging waste management: the CONAi solution (La gestione dei rifiuti di imballaggio: la soluzione CONAi). www.milomb.camcom.it/c/document library/get file?uuid=f77db514-6fe1-4913-ac1728772257d70a\&groupld=10157.

Cordella, M., Bauer, I., Lehmann, A., Schulz, M., Wolf, O., 2015. Evolution of disposable baby diapers in Europe: life cycle assessment of environmental impacts and identification of key areas of improvement. J. Clean. Prod. 95, 322-331.

Deloitte, 2011. Absorbent hygiene product: comparative life cycle assessment. Report prepared by Deloitte LLP ("Deloitte") for Knowaste Ltd, London.

De Jong, G., Schroten, A., Van Essen, H., Otten, M., Bucci, P., 2010. Price sensitivity of European road freight transport: towards a better understanding of existing results. A report for Transport \& Environment. https://www.transportenvironment.org/sites/te/files/media/2010 07 price sensitivity road freight significance ce.pdf.

DYCLE, 2018. The DYCLE project. https://dycle.org/en.

EC, 2011. Roadmap to a resource efficient Europe. Communication from the Commission to the European Parliament, the Council, the European Economic and Social Committee and the Committee of the regions, $\operatorname{COM}(2011)$ 571, European Commission (EC) Brussels.

EC, 2014a. A policy framework for climate and energy in the period from 2020 to 2030. Communication from the Commission to the European Parliament, the Council, the European Economic and Social Committee and the Committee of the Regions COM(2014) 15 final, European Commission (EC) Brussels.

EC, 2014b. Establishing the ecological criteria for the award of the EU Ecolabel for absorbent hygiene products. Commission Decision of 24 October 2014 (notified under document C(2014) 7735) (2014/763/EU). L 320/46. Official Journal of the European Union, European Commission (EC) Brussels. 
EC, 2015. The Paris Protocol: a blueprint for tackling global climate change beyond 2020. Energy Union Package. Communication from the Commission to the European Parliament and the Council. COM(2015) 81 final/2, European Commission (EC) Brussels.

EDANA, 2008. Sustainability report 2007-2008: absorbent hygiene products. European Disposables and Nonwovens Association (EDANA), Brussels.

EDANA, 2011. Sustainability report 2011. European Disposables and Nonwovens Association (EDANA), Brussels.

EDANA, 2015. Sustainability report. European Disposables and Nonwovens Association (EDANA), Brussels.

EEA, 2013. Final energy consumption by sector and fuel. Indicator assessment. Data and maps. European Environment Agency (EEA), Brussels.

EEA, 2014. Annual European Union greenhouse gas inventory 1990-2012 and inventory report 2014. Submission to the UNFCCC Secretariat. Technical report No 09/2014. European Environment Agency (EEA), Brussels.

Ehrenfeld, J., 2005. Eco-efficiency Philosophy, Theory, and Tools. J. Ind. Ecol. 9(4), 6-8.

EMF, 2015 Growth within: a circular economy vision for a competitive Europe. Ellen MacArthur Foundation (EMF), Isle of Wight.

Environment Agency, 2008. An updated life cycle assessment study for disposable and reusable nappies. Science report: SC010018/SR2, Bristol.

Espinosa-Valdemara, R.M., Sotelo-Navarro, P.X., Quecholac-Pina, X. García-Rivera, M.A., Beltrán-Villavicencio, M., Ojeda-Benítez, S., Vázquez-Morillas, A., 2014. Biological recycling of used baby diapers in a small-scale composting system. Res. Cons. Recycl. 87, $153-157$.

EU, 2010. Smarter and Greener. Consuming and producing sustainably. European Union, EU), Publications Office of the European Union, Luxembourg.

Euromonitor International, 2015. Tissue and Hygiene: Euromonitor from trade sources/national statistics, London.

Eurostat, 2017. Net earnings and taxes. Annual net earnings. http://ec.europa.eu/eurostat/web/labour-market/earnings/database.

Eurostat, 2018a. Municipal waste generation in the EU Member States. http://ec.europa.eu/eurostat/web/products-eurostat-news/-/DDN-20180123-1.

Eurostat, 2018b. Electricity price statistics. http://ec.europa.eu/eurostat/statisticsexplained/index.php/Electricity price statistics.

Eurostat, 2018c. Gas prices for non-household consumers: bi-annual data (from 2007 onwards). http://appsso.eurostat.ec.europa.eu/nui/show.do?dataset=nrg pc 203\&lang=en.

Eurostat, 2018d. Material prices for recyclates. http://ec.europa.eu/eurostat/web/waste/prices-for-recyclates.

Eurostat, 2018e. Greenhouse gas emission statistics: emission inventories. Statistics explained. https://ec.europa.eu/eurostat/statistics-explained/pdfscache/1180.pdf.

Fameccanica, 2018. LIFE GLUELESS ${ }^{\text {TM }}$ "petrol based glue and energy consumption reduction in diapers production processes" (LIFE12 ENV/IT/000423). http://glueless.fameccanica.com/en/.

FATER, 2015. Recycling of Absorbent Hygiene Products (AHPs) waste. https://innovationspartnerschaft.at/uploads/5ab4e1faebca5.pdf.

FEFCO and Cepi, 2012. Life cycle studies 2012. European Database for Corrugated Board, Brussels.

Graedel, T.E.H., Allenby, B.R., 2006. Industrial ecology and sustainable engineering. Pearson, London.

Gontia, P., Janssen, M., 2016. Life cycle assessment of bio-based sodium polyacrylate production from pulp mill side streams: case study of thermo-mechanical and sulfite pulp mills. J. Clean. Prod. 131, 475-484.

Jensen, A.A., Remmen, A., 2006. Background report for a UNEP guide to life cycle management: a bridge to sustainable products. Division of Technology, Industry and Economics, United Nations Environment Programme (UNEP), Paris. 
Hakala, S., Virtanen, Y., Meinander, K., Tanner, T., 1997. Live-cycle assessment, comparison of biopolymer and traditional diaper system. Technical Research Centre of Finland, VTT Tiedotteita - Meddelanden - Research notes 1876, Espoo.

Hogg, D., 2002. Costs for municipal waste management in the EU. Final report to Directorate General Environment, European Commission. http://ec.europa.eu/environment/waste/studies/pdf/eucostwaste.pdf.

Hunkeler, D., Lichtenvort, K., Rebitzer, G., 2008. Environmental life cycle costing. Society of Environmental Toxicology and Chemistry (SETAC), Pensacola.

ISO 2006a. ISO 14040. Environmental management - life cycle assessment - principles and framework. International Organization for Standardization (ISO), Geneva.

ISO 2006b. ISO 14044. Environmental management - life cycle assessment - requirements and guidelines. International Organization for Standardization (ISO), Geneva.

ISO 2012. ISO 14045. Environmental management - eco-efficiency assessment of product systems - principles, requirements and guidelines. International Organization for Standardization (ISO). Geneva, Switzerland.

ISPRA, 2018. Cost per capita and $\mathrm{kg}$ of the management of municipal wastes in Italy - year 2016 (Costi di gestione nazionali e per macroarea - Composizione del campione di comuni e riepilogo dei relativi costi totali medi di gestione pro capite e per $\mathrm{kg}$ di rifiuto, regioni Italia - Anno 2016). Istituto Superiore per la Protezione e la Ricerca Ambientale (ISPRA), Centro Nazionale per il ciclo dei rifiuti, Roma.

McDonough, W., Braungart, M., 2002. Cradle to cradle: remaking the way we make things. North Point, New York.

Mendoza, J.M.F., Sharmina, M., Gallego-Schmid, A., Heyes, G., Azapagic, A., 2017. Integrating backcasting and eco-design for the circular economy: the BECE framework. J. Ind. Ecol. 21(3), 526-544.

Mendoza, J.M.F., Popa, S.A., D'Aponte, F., Gualtieri, D., Azapagic, A., 2019. Resource and environmental savings driven by material optimisation and glue removal in clean diaper manufacturing. J. Clean. Prod., 210, 916-928.

Mirabella N, Castellani V, Sala S, 2013. Life cycle assessment of bio-based products: a disposable diaper case study. Int. J. Life Cycle Assess. 18, 1036-1047.

Llic, D.D., Eriksson, O., Ödlund, L., Åberg, M., 2018. No zero burden assumption in a circular economy. J. Clean. Prod., 182: 352-362.

O'Brien, K.R., Olive, R., Hus, Y.C., Bell, R., Morris, L., Kendall, N., 2009. Life cycle assessment: reusable and disposable nappies in Australia. In: Australian Life Cycle Assessment Society Conference - 6th Australian Conference on Life Cycle Assessment. Melbourne, Australia.

Swarr, T., Hunkeler, D., Klöpffer, W., Pesonen, H-L., Ciroth, A., Brent, A., Pagan, R., 2011. Environmental life-cycle costing: a code of practice. Int. J. Life Cycle Assess. 16(5), 389391.

WBCSD, 2006. Eco-efficiency: learning module. World Business Council for Sustainable Development (WBCSD), Geneva.

Weisbrod, A.V., Van Hoof, G., 2012. LCA-measured environmental improvements in Pampers ${ }^{\circledR}$ diapers. Int. J. Life Cycle Assess. 17, 145-153.

WRAP, 2016. Plastics market situation report 2016. Waste and Resources Action Programme (WRAP), Banbury. 


\section{Disposable baby diapers: life cycle costs, eco-efficiency and circular economy}

Joan Manuel F. Mendoza, Francesco D'Aponte, Diego Gualtieri and Adisa Azapagic

\section{SUPPORTING INFORMATION}

Table S1. Life cycle inventory and costs of standard and glueless disposable baby diapers at the EU level.

\begin{tabular}{|c|c|c|c|c|c|c|}
\hline \multirow{2}{*}{$\begin{array}{l}\text { Life cycle } \\
\text { stages }\end{array}$} & \multirow{2}{*}{\multicolumn{2}{|c|}{ Diaper components/unit operations/activities }} & \multicolumn{2}{|c|}{ Amount/1,000 diapers } & \multicolumn{2}{|c|}{ Cost (€/1,000 diapers) } \\
\hline & & & Standard & Glueless & Standard & Glueless \\
\hline \multirow[t]{17}{*}{ Raw materials } & \multirow[t]{2}{*}{ Elastic cuffs } & NW cuff $(\mathrm{kg})$ & 1.16 & 1.16 & 2.63 & 2.63 \\
\hline & & Elastics (kg) & 0.02 & 0.02 & 0.20 & 0.20 \\
\hline & \multirow{2}{*}{$\begin{array}{l}\text { Topsheet-ADL } \\
\text { construction }\end{array}$} & NW topsheet $(\mathrm{kg})$ & 1.03 & 1.03 & 2.42 & 2.42 \\
\hline & & ADL $(\mathrm{kg})$ & 1.89 & 1.89 & 5.05 & 5.05 \\
\hline & \multirow[t]{5}{*}{ Absorbent core } & Upper tissue (kg) & 0.56 & 0.56 & 1.41 & 1.41 \\
\hline & & Lower tissue (kg) & 0.63 & 0.63 & 1.52 & 1.52 \\
\hline & & ATB layer $(\mathrm{kg})$ & 0.00 & 2.11 & 0.00 & 6.33 \\
\hline & & Fluff pulp (kg) & 12.70 & 3.03 & 12.12 & 2.89 \\
\hline & & $\operatorname{SAP}(\mathrm{kg})$ & 15.15 & 14.14 & 30.30 & 28.28 \\
\hline & \multirow{2}{*}{$\begin{array}{l}\text { Front and elastic back } \\
\text { ears }\end{array}$} & Elastic NW back ears (kg) & 1.55 & 1.55 & 10.10 & 10.10 \\
\hline & & NW for front ears $(\mathrm{kg})$ & 0.26 & 0.26 & 0.51 & 0.51 \\
\hline & \multirow{3}{*}{$\begin{array}{l}\text { Composite backsheet } \\
\text { with frontal tape }\end{array}$} & NW backsheet (kg) & 2.24 & 2.24 & 5.05 & 5.05 \\
\hline & & Backsheet film (kg) & 1.88 & 1.88 & 8.08 & 8.08 \\
\hline & & Frontal tape $(\mathrm{kg})$ & 0.21 & 0.21 & 8.08 & 8.08 \\
\hline & Hot-melt adhesive & Glue $(\mathrm{kg})$ & 0.95 & 0.32 & 3.37 & 1.13 \\
\hline & \multirow{2}{*}{ Packaging } & Corrugated cardboard (kg) & 0.09 & 0.07 & 0.12 & 0.09 \\
\hline & & Plastic film $(\mathrm{kg})$ & 0.20 & 0.20 & 0.28 & 0.21 \\
\hline \multirow{17}{*}{$\begin{array}{l}\text { Diaper } \\
\text { manufacturing }\end{array}$} & \multirow[t]{2}{*}{ Motors } & Electricity (kWh) & 1.00 & 1.03 & 0.14 & 0.15 \\
\hline & & Maintenance (lubricants, kg) & $9.9 \times 10^{-4}$ & $1.0 \times 10^{-3}$ & $4.3 \times 10^{-3}$ & $4.8 \times 10^{-3}$ \\
\hline & \multirow[t]{2}{*}{ Vacuum system } & Electricity (kWh) & 1.83 & 1.83 & 0.26 & 0.26 \\
\hline & & Maintenance (lubricants, kg) & $1.8 \times 10^{-3}$ & $1.8 \times 10^{-3}$ & $7.5 \times 10^{-5}$ & $7.5 \times 10^{-5}$ \\
\hline & \multirow[t]{2}{*}{ Chillers } & Electricity (kWh) & 0.02 & 0.00 & $3.2 \times 10^{-3}$ & 0.00 \\
\hline & & Maintenance (lubricants, kg) & $2.2 \times 10^{-5}$ & 0.00 & $8.0 \times 10^{-3}$ & 0.00 \\
\hline & \multirow[t]{2}{*}{ Glue applicators } & Electricity (kWh) & 0.24 & 0.03 & 0.03 & $4.7 \times 10^{-3}$ \\
\hline & & Maintenance (L\&S, kg) & $5.3 \times 10^{-3}$ & $7.7 \times 10^{-4}$ & $3.1 \times 10^{-1}$ & $3.1 \times 10^{-2}$ \\
\hline & \multirow[t]{2}{*}{ Pneumatic unit } & Electricity (kWh) & 0.25 & 0.00 & 0.04 & 0.00 \\
\hline & & Maintenance (lubricants, kg) & $2.5 \times 10^{-4}$ & 0.00 & $2.6 \times 10^{-3}$ & 0.00 \\
\hline & \multirow[t]{2}{*}{ Ultrasonic systems } & Electricity $(\mathrm{kWh})$ & 0.00 & 0.02 & 0.00 & $3 . .2 \times 10^{-}$ \\
\hline & & Maintenance (lubricants, kg) & 0.00 & $2.3 \times 10^{-5}$ & 0.00 & $3.0 \times 10^{-3}$ \\
\hline & \multirow[t]{2}{*}{ Thermo-mechanical unit } & Electricity (kWh) & 0.00 & 0.08 & 0.00 & 0.01 \\
\hline & & Maintenance (lubricants, kg) & 0.00 & $8.3 \times 10^{-5}$ & 0.00 & $5.0 \times 10^{-5}$ \\
\hline & \multirow[t]{2}{*}{ Heat-sealers } & Electricity (kWh) & 0.01 & 0.02 & $1.6 \times 10^{-3}$ & $2.8 \times 10^{-3}$ \\
\hline & & Maintenance (lubricants, kg) & $1.1 \times 10^{-5}$ & $1.8 \times 10^{-5}$ & $2.5 \times 10^{-5}$ & $4.4 \times 10^{-5}$ \\
\hline & Labour & Staff & - & - & 1.75 & 1.21 \\
\hline \multirow[t]{3}{*}{$\begin{array}{l}\text { Transport } \\
\text { operations }\end{array}$} & Raw materials & $\begin{array}{l}\text { Ocean freighter and } \\
\text { Lorries } 20-40 \mathrm{t}(\mathrm{tkm})\end{array}$ & 158.07 & 62.28 & 3.03 & 2.05 \\
\hline & Final product & Lorry $40 \mathrm{t}(\mathrm{tkm})$ & 20.11 & 15.50 & 2.79 & 2.15 \\
\hline & Diaper wastes & Lorry $40 \mathrm{t}(\mathrm{tkm})$ & 2.02 & 1.56 & 4.22 & 3.26 \\
\hline Waste & Recycling & Packaging waste & 0.15 & 0.13 & 0.02 & 0.02 \\
\hline management & Incineration & Packaging and used diapers & 15.36 & 11.86 & 4.76 & 3.67 \\
\hline & Landfilling & Packaging and used diapers & 25.00 & 19.29 & 0.66 & 0.51 \\
\hline
\end{tabular}

Acronyms: ADL - Acquisition and distribution layer; ATB - Air-Through bonded layer; NW - Nonwoven; SAP Superabsorbent polymer; L\&S - Lubricants and Solvents. 


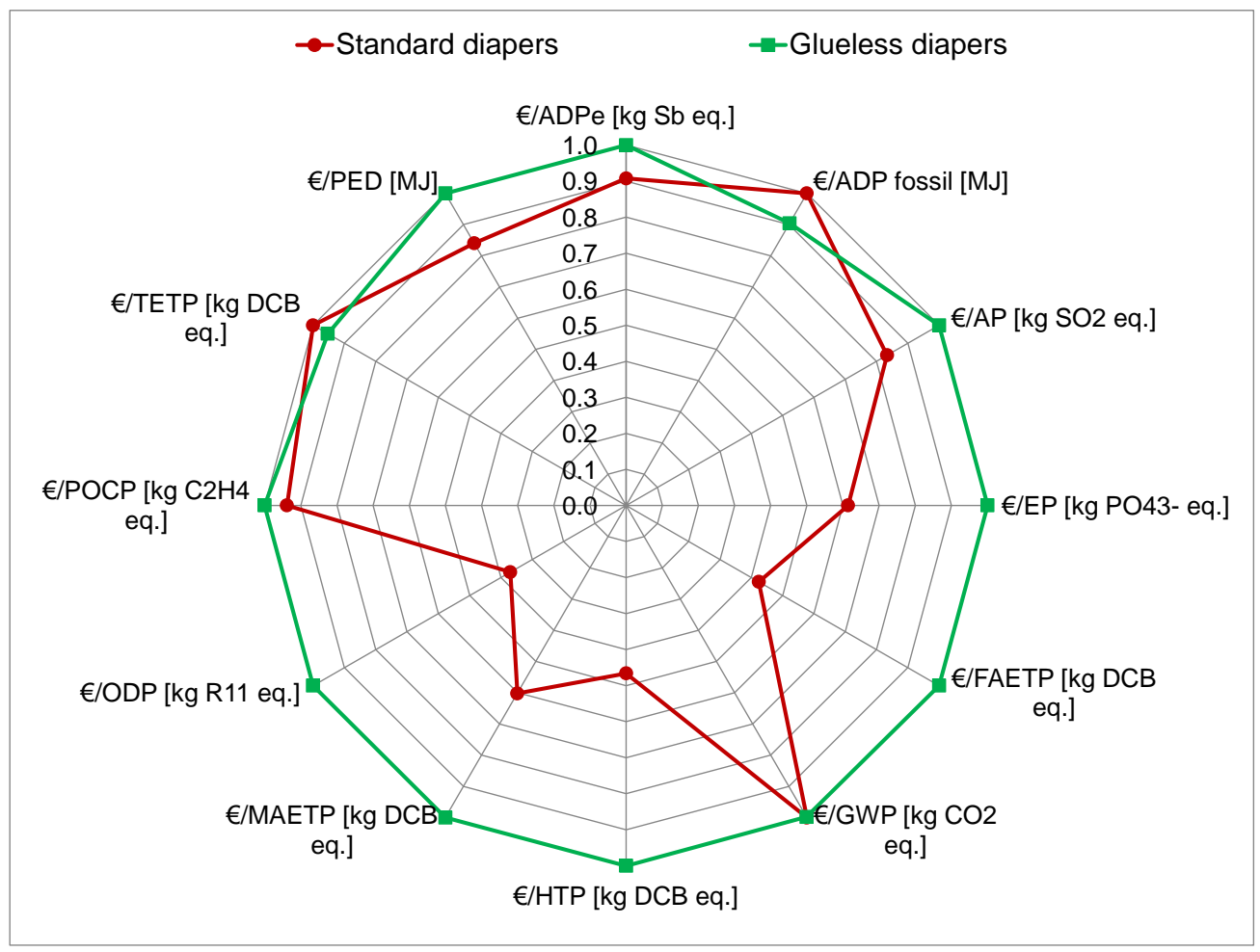

Figure S1. Normalised eco-efficiency indicators (€/impact) for standard and glueless diapers.

(PED: primary energy demand, $\mathrm{ADP}_{\mathrm{e}}$ : abiotic depletion potential of elements, $\mathrm{ADP}_{\mathrm{f}}$ : abiotic depletion potential of fossil resources, AP: acidification potential, EP: eutrophication potential, GWP: global warming potential, HTP: human toxicity potential, MAETP: marine aquatic ecotoxicity potential, FAETP: freshwater aquatic ecotoxicity potential, ODP: ozone depletion potential, POCP: photochemical oxidants creation potential, TETP: terrestrial ecotoxicity potential. DCB - dichlorobenzene). 